Western University Scholarship@Western

Undergraduate Honors Posters

Psychology Department

$4-2014$

[Ö] A Twin Study

callista forchuk

Western University, cforchu@uwo.ca

Follow this and additional works at: https://ir.lib.uwo.ca/psychd_posters

Part of the Other Psychology Commons, and the Personality and Social Contexts Commons

Citation of this paper:

forchuk, callista, ":obi:Individual Differences in Ownership Reasoning: A Twin Study" (2014). Undergraduate Honors Posters. 1. https://ir.lib.uwo.ca/psychd_posters/1 


\section{Individual Differences in Ownership Reasoning: A Twin Study}

Callista Forchuk; Thesis Advisor: Philip A. Vernon

University of Western Ontario

\section{ABSTRACT}

This study is the first to investigate the extent to which environmental and genetic factors contribute to aspects of ownership reasoning. 65 pairs of adult monozygotic (MZ) twins, and 16 pairs of same-sex dizygotic (DZ) twins completed a 24-item ownership questionnaire, which included items on new ownership and appropriate transfers of ownership. MZ correlations were larger than DZ correlations for both aspects of ownership reasoning, and univariate model fitting indicated that genetic and non-shared environmental factors could account for all individual variation, with shared environmental factors contributing nonsignificantly. Heritabilities ranged from .36-.57 over both factors. The results support the notion that individual differences in ownership reasoning have a significant genetic basis.

\section{INTRODUCTION}

Ownership and property are imperative for survival in all species, and include a variety of consequences psychologically, behaviourally, and socially.

\section{Inferring ownership in adults}

- use of heuristics including first possession heuristic (first possessor as owner), and judging whose actions were necessary for possession

\section{Evidence for a genetic influence on} ownership reasoning:

Use of adult-like heuristics at young age:

- Favor first possessor as owner of objects (age 2) and ideas (age 6)

\section{INTRODUCTION}

(Cont'd)

Cross-Cultural Similarities

- Age 5+: communal (kibbutz) vs. American show similar understanding of property

- Cultures without private land laws (East Timor) favor a first possession rule

- Evidence of first possession heuristic in animals (e.g., butterflies, birds, baboons)

\section{Hypotheses:}

H1: $M Z$ will be greater than DZ correlations

H2: Genes will contribute significantly to response variance in model fitting analyses

\section{METHOD}

Participants: 65 pairs monozygotic (MZ) twins, 16 dizygotic (DZ) twins (ages: 19-82)

Measures: 24-item ownership questionnaire measuring two factors (12 items each):

(1) Who is the owner of a non-owned item?

(2) Is it appropriate to borrow without permission?

Each item involves a short story followed by a

statement. Participants rate their agreement on a 7point scale.

Data Analysis: Correlations for $\mathrm{MZ}$ and for $\mathrm{DZ}$ twins: univariate model fitting: estimate role of environment (common $[C]$ and unique $[E]$ ), and genetic infuences $(A)$ on response variation.

\section{RESULTS}

- $\mathrm{MZr}$ are greater than $\mathrm{DZr}$, implies genetic influence

- A and E components account for data; suggests importance of unique environment and genetics.

- Heritabilities range from .36-.57

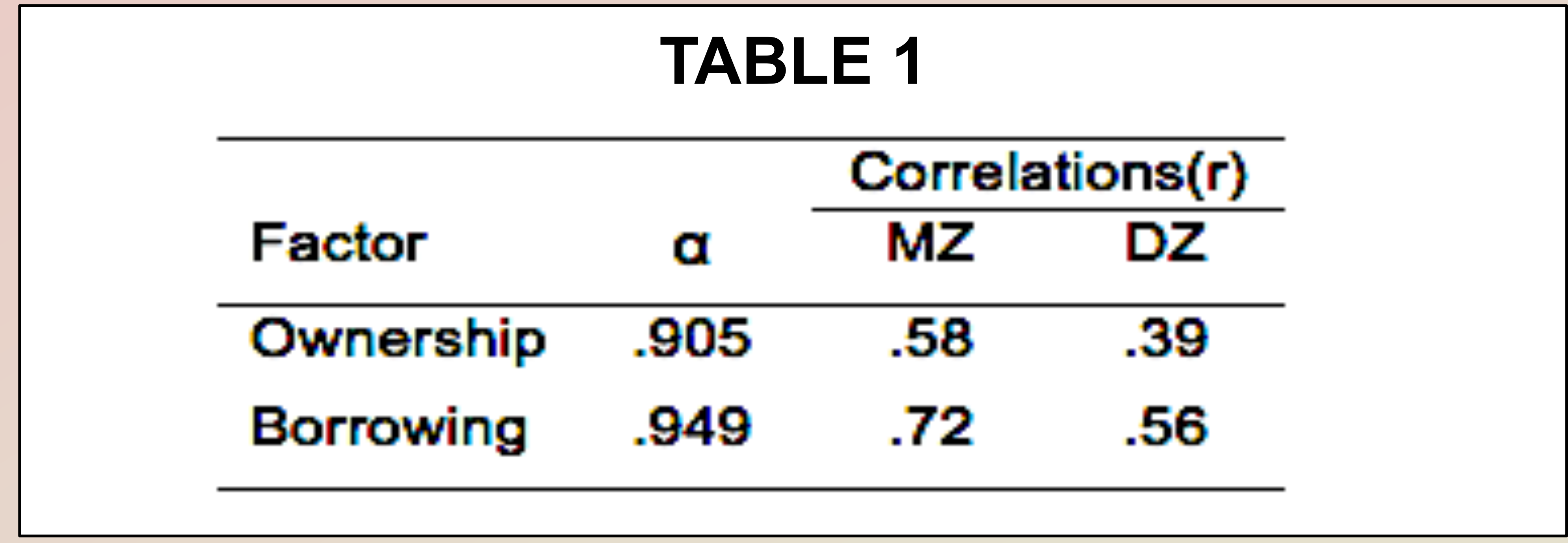

\section{TABLE 2}

\begin{tabular}{llllll}
\hline & & \multicolumn{3}{l}{ Parameter estimates $(95 \% \mathrm{Cl})$} & \\
\cline { 3 - 5 } Factor & \multirow{2}{*}{ Model } & \multicolumn{1}{c}{$\mathrm{a}^{2}$} & \multicolumn{1}{c}{$\mathrm{c}^{2}$} & \multicolumn{1}{c}{$\mathrm{\theta}^{2}$} & \multicolumn{1}{c}{ AIC } \\
\hline Ownership & ACE & $.37(.00-$ & $.04(.00-$ & $.59(.41-$ & -5.04 \\
& & $.59)$ & $.53)$ & $.81)$ & \\
& AE & $.41(.19-$ & & $.59(.41-$ & -7.04 \\
& & $.59)$ & & $.80)$ & \\
\hline Borrowing & ACE & $.36(.00-$ & $.20(.00-$ & $.44(.29-$ & -5.30 \\
& & $.71)$ & $.65)$ & $.64)$ & \\
& AE & $.57(.37-$ & & $.43(.29-$ & -7.10 \\
& & $.71)$ & & $.63)$ & \\
\hline
\end{tabular}

\section{DISCUSSION AND CONCLUSION}

Findings support our hypotheses, there appears to be a significant genetic influence to ownership reasoning:

- consistent with authors postulating a genetic component, and with research on personality traits

- Opposes purely environmental explanations

Limitations:

- Small $\mathrm{n}$ for DZ

- Only covers a fraction of all ownership facets Possibility for errors or bias in self-report

This study addresses a long posed question and opens the door for further research. 